\title{
PENGARUH PUPUK TANIJAU DAN NPK MUTIARA TERHADAP PERTUMBUHAN DAN HASIL TANAMAN SEMANGKA (Citrullus vulgaris Schard) VARIETAS ANGELA FI
}

\author{
Nur Hidayat ${ }^{1}$ \\ ${ }^{1}$ Agroteknologi, Fakultas Pertanian, Universitas 17 Agustus 1945 Samarinda 75124, \\ Indonesia. \\ E-Mail:nur20428@gmail.com
}

\begin{abstract}
ABSTRAK
Pengaruh Pupuk Tanijau dan NPK Mutiara Terhadap Pertumbuhan Dan Hasil Tanaman Semangka (Citrullus vulgaris Schard) Varietas Angela F1. Tujuan Penelitian untuk mengetahui pengaruh pupuk Tanijau dan NPK Mutiara serta interaksinya terhadap pertumbuhan dan hasil tanaman semangka varietas Angela F1 serta untuk memperoleh dosis pupuk Tanijau dan NPK Mutiara yang sesuai untuk meningkatkan produksi tanaman semangka (Citrullus vulgaris Schard) Varietas Angela F1.

Penelitian menggunakan Rancangan Acak Kelompok (RAK) dengan analisis faktorial 4 x 4 dan terdiri atas 3 ulangan (blok). Faktor pertama adalah Dosis Pupuk Tanijau (A) yang terdiri atas 4 taraf. Faktor kedua adalah dosis pupuk NPK Mutiara $(\mathrm{N})$ yang terdiri atas 4 taraf.

Perlakuan pupuk Tanijau tidak berpengaruh nyata terhadap parameter umur panen dan berpengaruh sangat nyata terhadap parameter panjang tanaman umur 20, 40, 60 hari setelah tanam, umur keluar bunga, diameter buah, berat buah per petak produksi serta produksi buah. Produksi buah tertinggi terdapat pada perlakuan $\mathrm{a}_{3}$ (30 ton/ha), yaitu 38,23 ton/ha.

Perlakuan pupuk NPK Mutiara tidak berpengaruh nyata terhadap parameter umur panen tetapi berpengaruh nyata terhadap parameter umur keluar bunga dan berpengaruh sangat nyata terhadap panjang tanaman umur 20, 40, 60 hari setelah tanam, diameter buah, berat buah per petak produksi serta produksi buah. Produksi buah tertinggi terdapat pada perlakuan $\mathrm{n}_{3}(900 \mathrm{~kg} / \mathrm{ha})$, yaitu $28,44 \mathrm{~kg} / \mathrm{ha}$.

Interaksi perlakuan antara pupuk Tanijau dan pupuk NPK Mutiara tidak berpengaruh nyata terhadap parameter panjang tanaman umur 20 hari setelah tanam, umur keluar bunga, umur panen, diameter buah, berat buah per petak produksi dan produksi buah tetapi berpengaruh nyata terhadap parameter panjang tanaman umur 40 dan 60 hari setelah tanam. Produksi buah tertinggi terdapat pada perlakuan $\mathrm{a}_{3} \mathrm{n}_{2}(30 \mathrm{ton} / \mathrm{ha}$ dan $600 \mathrm{~kg} / \mathrm{ha}$ ), yaitu 41,00 ton/ha.
\end{abstract}

Kata kunci : Pertumbuhan, Pupuk NPK Mutiara, Pupuk Tanijau, Pertumbuhan, Tanaman semangka.

\begin{abstract}
The Effect of Tanijau and NPK Mutiara Fertilizers on the Growth and Yield of Watermelon Plant (Citrullus vulgaris Schard) Angela F1 Variety. The aim of the study was to determine the effect of Tanijau and NPK Mutiara fertilizers and their interaction on the growth and yield of Angela F1 watermelon variety and to obtain the appropriate dosages of Tanijau and NPK Mutiara fertilizers to increase the production of watermelon.

The study used a Randomized Block Design (RBD) with $4 \times 4$ factorial analysis and consisted of 3 replications (blocks). The first factor was the Tanijau fertilizer dosage (A) which consists of 4 levels. The second factor was the NPK Mutiara fertilizer dosage $(N)$ consisting of 4 levels. Research results showed that Tanijau fertilizer treatment had no significant effect on the parameters of age of crop harvested but it had a very significant effect on the length of plants at aged 20-, 40-, and 60-days after planting, age of crop flowered, fruit diameter, fruit weight per plot and fruit production. The highest fruit production was found at the $a_{3}$ treatment ( 30 tons $/ \mathrm{ha}$ ) which was 38.23 tons $/ \mathrm{ha}$.

Treatment of NPK Mutiara fertilizer did not significantly affect the parameters of age of crop harvested, but it had significant effect on the age of crop flowered and had a very significant effect on the length of plants at aged 20-, 40-, and 60-days after planting, fruit diameter, fruit weight per plot and fruit production. The highest fruit production is in treatment $n_{3}(900 \mathrm{~kg} / \mathrm{ha})$ which was $28.44 \mathrm{~kg} / \mathrm{ha}$.
\end{abstract}


The treatment of interaction between Tanijau fertilizer and NPK Mutiara fertilizer did not significantly affect the length of plants at aged 20-days after planting, the age of crop flowered, age of crop harvested, fruit diameter, fruit weight per plot and fruit production. But it had significant effect on the length of plants at aged 40- and 60-days after planting. The highest fruit production was found at $a_{3} n_{2}$ treatment (30 tons/ha and $600 \mathrm{~kg} / \mathrm{ha}$ ) which was 41.00 tons/ha.

Key words : Growth, NPK mutiara fertilizers, Tanijau fertilizers, Watermelon plant.

\section{PENDAHULUAN}

Semangka (Citrullus vulgaris Schard) termasuk salah satu jenis tanaman buah-buahan semusim yang mempunyai arti penting bagi perkembangan sosial ekonomi rumah tangga maupun negara. Pengembangan budidaya komoditas ini mempunyai prospek yang lebih baik karena dapat mendukung upaya peningkatan pendapatan petani, pengentasan kemiskinan, perbaikan gizi masyarakat, perluasan kesempatan kerja, pengurangan impor dan peningkatkan ekspor nonmigas (Barus dan Syukri, 2008).

Menurut sejarahnya, semangka merupakan tanaman menjalar yang berasal dari Afrika. Tanaman ini pertama kali disebarkan dari daratan Cina. Keberadaanya di Indonesia diperkirakan berasal dari para pedagang dan pengungsi dari Cina. Saat ini sudah banyak jenis semangka berbiji yang bisa kita jumpai, baik semangka lokal maupun hibrida. Di Indonesia banyak dikembangkan diantaranya Indramayu, Cirebon, Madiun, Madura, Lombok dan Sumatera Utara (Barus dan Syukri, 2008).

Buah semangka termasuk dalam keluarga buah labu - labuan (Cucurbitaceae), masih sekerabat dengan melon (Cucumis melo) dan mentimun (Cucumis sativum). Buah ini sangat disukai karena banyak mengandung air. Oleh sebab itu, penyebaran dan budidaya buah semangka menjadi lebih cepat (Soedarya, 2009).

Kandungan kalium dalam semangka cukup tinggi sehingga dapat membantu kerja jantung dan menormalkan tekanan darah. Likopen merupakan antioksidan yang lebih unggul dari vitamin C. Biji semangka kaya zat gizi dengan kandungan minyak berwarna kuning sebanyak $20-45 \%$; protein $30-$ 40\%; sitrulin; vitamin B12 dan enzim urease. Senyawa aktif kukurbositrin pada biji semangka dapat memacu kerja ginjal dan menjaga tekanan darah agar tetap normal (Soedarya, 2009).

Varietas semangka yang beredar di pasaran sangat beragam yaitu semangka hibrida dan bukan hibrida (termasuk varietas lokal). Varietas semangka hibrida (F1) merupakan persilangan antara 2 atau lebih induk semangka yang memiliki sifat - sifat unggul yaitu produksi tinggi dan tahan serangan penyakit. Jenis varietas semangka hibrida yaitu New dragon, Diamond, dan Yellow baby. Varietas semangka bukan hibrida merupakan varietas semangka yang dihasilkan dari hasil seleksi galur murni suatu varietas yang mempunyai salah satu sifat unggul. Jenis varietas semangka bukan hibrida yaitu varietas Sugar baby (Prajnanta, 2001).

Ada beberapa faktor penting dalam usaha budidaya tanaman semangka selain penyemaian, persiapan lahan, penanaman, pemeliharaan dan panen. Faktor yang tidak kalah penting adalah benih unggul dan pemupukan. Benih unggul merupakan kunci utama dalam menentukan tingkat keberhasilan budidaya tanaman semangka. Salah satu benih unggul yang dapat digunakan yaitu benih semangka Angela F1. Benih semangka Angela F1 merupakan tanaman semangka yang banyak diminati oleh masyarakat untuk dibudidayakan karena menghasilkan semangka berbiji, bentuk 
buah bulat, warna daging kuning, rasa buah manis, berat buah mampu mencapai $6,2 \mathrm{~kg}$ dan umur panen hanya 65 hari setelah tanam. Pemupukan merupakan kunci kesuburan tanah karena berisi satu atau lebih unsur untuk menggantikan unsur yang terhisap oleh akar tanaman. Pemupukan dapat menggunakan pupuk organik dan pupuk anorganik, penggabungan kedua jenis pupuk tersebut sangat dianjurkan untuk memacu pertumbuhan dan hasil tanaman supaya maksimal.

Salah satu pupuk organik yang dapat digunakan yaitu pupuk Tanijau. Tanijau merupakan bahan - bahan organik seperti pangkasan daun tanaman, kotoran ternak dan sampah organik lainnya yang telah dikomposkan. Manfaat dari pupuk Tanijau untuk memperbaiki jaringan sel tanaman sehingga tanaman tumbuh dan berkembang, memperbaiki kerusakan tanah, memelihara ekosistem dan kesuburan tanah. Keunggulan dari pupuk Tanijau untuk meningkatkan pertukaran udara, menurunkan tingkat kekerasan lapisan permukaan tanah, mengandungkan unsur hara makro dan mikro, menghilangkan residu kimia, efektif dan ekonomis (Unitekborneo, 2015).

Menurut Hadisuwito (2012), kelebihan pupuk organik adalah mengandung unsur hara makro dan mikro lengkap, tetapi jumlahnya sedikit, dapat memperbaiki struktur tanah, sehingga tanah menjadi gembur, memiliki daya simpan air yang tinggi, tanaman lebih tahan terhadap serangan penyakit, meningkatkan aktivitas mikroorganisme tanah yang menguntungkan, memiliki residual effect yang positif, sehingga tanaman yang ditanam pada musim berikutnya tetap baik pertumbuhan dan produktivitasnya.

Pemberian pupuk organik perlu di imbangi dengan pemakaian pupuk anorganik yaitu pupuk NPK Mutiara.
Menurut Novizan (2007), pupuk NPK Mutiara adalah pupuk majemuk yang memiliki komposisi unsur hara yang seimbang dan dapat larut secara perlahan - lahan. Pupuk NPK Mutiara memiliki keunggulan antara lain sifatnya yang lambat larut sehingga mengurangi kehilangan unsur hara akibat pencucian, penguapan dan penjerapan oleh koloid tanah. Selain itu, pupuk NPK Mutiara memiliki kandungan hara yang seimbang, lebih efisien dalam pengaplikasian dan sifatnya tidak terlalu higroskopis sehingga tahan simpan dan tidak mudah menggumpal.

Menurut Sigit (2001) manfaat pupuk NPK Mutiara untuk memacu pertumbuhan tanaman terutama pada fase vegetatif, merangsang pertumbuhan atau perkembangan akar, membantu pembentukan protein, memperkuat jaringan tanaman dan berperan membentuk antibodi tanaman terhadap penyakit serta kekeringan.

Berdasarkan uraian diatas, maka dilakukan penelitian : Pengaruh Pupuk Tanijau dan NPK Mutiara Terhadap Pertumbuhan Dan Hasil Tanaman Semangka (Citrullus vulgaris Schard) varietas Angela F1. Tujuan penelitian adalah untuk mengetahui pengaruh pupuk Tanijau dan NPK Mutiara serta interaksinya terhadap pertumbuhan dan hasil tanaman semangka (Citrullus vulgaris Schard) varietas Angela F1. Untuk memperoleh dosis pupuk Tanijau dan NPK Mutiara yang sesuai untuk menghasilkan produksi yang tinggi pada tanaman semangka (Citrullus vulgaris Schard) varietas Angela F1.

\section{METODA PENELITIAN}

\subsection{Tempat dan Waktu}

Lokasi penelitian terletak di Desa Sidomulyo, Kecamatan Anggana, Kabupaten Kutai Kartanegara, 
Provinsi Kalimantan Timur. Pada bulan Maret-Juni 2018.

\subsection{Bahan dan Alat}

Bahan-bahan yang digunakan dalam penelitian ini adalah Benih semangka (Citrullus vulgaris Schard) varietas Angela F1, pupuk Tanijau, pupuk NPK Mutiara, insektisida Agrimec 18 EC, Furadan 3G dan fungisida Antracol 70 WP.

Sedangkan alat-alat yang digunakan dalam penelitian ini adalah arit, alat tulis menulis, ayakan tanah, cangkul, ember, gembor, hand sprayer, kamera, kaleng bekas susu bergerigi, meteran, pasak bambu, plastik mulsa, tali rafia, timbangan dan timbangan analitik.

\subsection{Rancangan Penelitian}

Rancangan yang digunakan dalam penelitian ini adalah Rancangan Acak Kelompok (RAK) dengan analisis faktorial $4 \times 4$ dan terdiri atas 3 ulangan (blok).

Adapun faktor perlakuan tersebut yaitu :

Faktor I adalah Dosis Pupuk Tanijau (A) yang terdiri atas 4 taraf,yaitu :

$\mathrm{a}_{0}=$ tanpa Pupuk Tanijau (kontrol)

$\mathrm{a}_{1}=10$ ton/ha setara dengan 1 $\mathrm{kg} /$ tanaman

$a_{2}=20$ ton/ha setara dengan 2 $\mathrm{kg} /$ tanaman

$\mathrm{a}_{3}=30$ ton/ha setara dengan 3 $\mathrm{kg} /$ tanaman

Faktor II adalah dosis pupuk NPK Mutiara (N) yang terdiri atas 4 taraf, yaitu

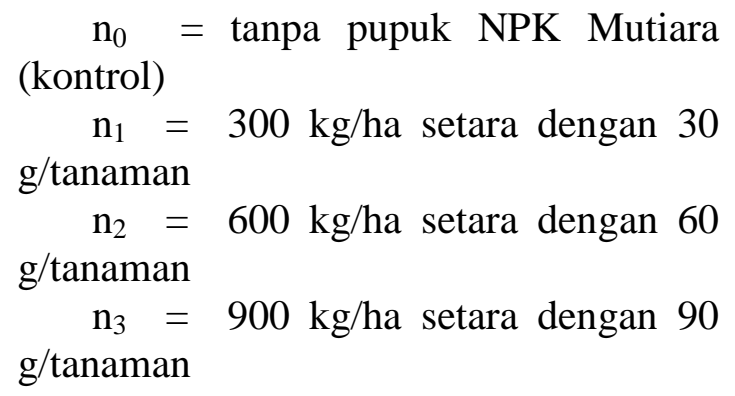

Dari kedua faktor perlakuan tersebut terdapat $4 \times 4$ kombinasi perlakuan yaitu

$\begin{array}{lll}\mathrm{a}_{0} \mathrm{n}_{0} & \mathrm{a}_{0} \mathrm{n}_{1} & \mathrm{a}_{0} \mathrm{n}_{2} \\ \mathrm{a}_{1} \mathrm{n}_{0} \mathrm{n}_{3} & \mathrm{a}_{1} \mathrm{n}_{1} & \mathrm{a}_{1} \mathrm{n}_{2} \\ \mathrm{a}_{2} \mathrm{n}_{0} \mathrm{a}_{1} \mathrm{n}_{3} & \mathrm{a}_{2} \mathrm{n}_{1} & \mathrm{a}_{2} \mathrm{n}_{2} \\ \mathrm{a}_{3} \mathrm{n}_{0} \mathrm{a}_{2} \mathrm{n}_{3} & \mathrm{a}_{3} \mathrm{n}_{1} & \mathrm{a}_{3} \mathrm{n}_{2} \\ \mathrm{a}_{3} \mathrm{n}_{3} & & \end{array}$

Setiap kombinasi perlakuan diulang sebanyak 3 kali sehingga jumlah satuan unit penelitian sebanyak 48 petak.

\subsection{Pelaksanaan Penelitian}

Persiapan Lahan

Lahan sebagai tempat penelitian terlebih dahulu dibersihkan dari gulma atau kayu - kayu dengan bertujuan agar tidak menggangu pertumbuhan akar tanaman semangka, kemudian tanah di cangkul sedalam $30 \mathrm{~cm}$. Kemudian dibagi menjadi 3 blok sebagai ulangan dengan jarak antar blok adalah 1,5 meter. Dalam setiap blok dibuat petak penelitian berukuran $4 \mathrm{~m}$ x 4 m sebanyak 16 petak sebagai satuan penelitian dengan jarak petak adalah $1 \mathrm{~m}$. Pada setiap petak penelitian dipasang plang kode perlakuan sesuai hasil acak sederhana dengan undian.

Pemberian pupuk Tanijau

Pemberian pupuk Tanijau pada setiap petak penelitian disesuaikan dengan dosis perlakuan yaitu $\left(\mathrm{a}_{0}\right)$ : tanpa pupuk Tanijau atau kontrol, $\left(\mathrm{a}_{1}\right)$ : dengan dosis pupuk Tanijau sebanyak 1 $\mathrm{kg} /$ tanaman, $\left(\mathrm{a}_{2}\right)$ : dengan dosis pupuk Tanijau sebanyak $2 \mathrm{~kg} /$ tanaman dan $\left(\mathrm{a}_{3}\right)$ : dengan dosis pupuk Tanijau sebanyak 3 kg/tanaman. Pemberian pupuk Tanijau diberikan 14 hari sebelum tanam dengan cara disebarkan merata pada permukaan lahan lalu digarukan agar tercampur rata dengan tanah. 


\section{Pemasangan Mulsa}

Mulsa dipasang di petak penelitian dan dipinggir mulsa ditancapkan pasak dari bambu agar tidak mudah lepas ditiup angin. Pemasangan mulsa dilakukan 7 hari sebelum tanam. Sebaiknya pemasangan mulsa dilakukan pada siang hari, karena plastik lebih lentur dan mudah dipasang.

Pembuatan Lubang Mulsa dan Lubang Tanam

Pelubangan mulsa dengan menggunakan bekas kaleng susu yang telah di modifikasi seperti gerigi dengan cara ditancapkan pada mulsa sambil diputar hingga tanahnya ikut terangkat dan membentuk lubang tanam dengan jarak $1 \mathrm{~m}$ x $1 \mathrm{~m}$. Kelebihan dari cara ini adalah dapat sekaligus membentuk lubang tanam di petak penelitian. Pembuatan lubang mulsa dan lubang tanah dilakukan 1 hari sebelum tanam.

\section{Seleksi Benih}

Benih semangka sebelum disemai direndam dalam air kemudian benih yang tenggelam diletakan diatas kertas koran yang sudah dibasahi lalu ditutup dengan kertas koran, kemudian dilakukan pemeraman selama 48 jam. Benih yang sudah berkecambah atau keluar calon akarnya sepanjang 2-3 mm, kemudian dipindah ke dalam polibag persemaian.

\section{Persemaian}

Media semai yang digunakan adalah campuran tanah bagian atas (top soil) dan kemudian media semai dimasukkan ke dalam polibag kecil ukuran 3 x $5 \mathrm{~cm}$. Polibag di persiapkan sebanyak 768 polibag sesuai dengan jumlah tanaman yang akan di teliti. Setelah itu, media semai di beri lubang tanam sedalam $2 \mathrm{~cm}$ kemudian benih disemai ke dalam polibag yang telah diisi media sebanyak 1 benih/ polibag.
Kemudian diberi naungan plastik diatasnya dengan lebar $100 \mathrm{~cm}$, tinggi 50 $\mathrm{cm}$ dan panjang disesuaikan yang dibutuhkan untuk menghindari hama, gulma dan penyakit.

\section{Pemeliharaan Bibit}

Bibit semangka yang telah disemai memerlukan penyiraman secara rutin. Agar tanaman tidak stress saat dipindah ke lahan, dilepas tutup plastik transparan setelah tumbuh dua sampai tiga helai daun atau bibit berumur 7-10 hari di atas biji lembaga. Tujuannya, agar bibit dapat beradaptasi dengan sinar matahari.

\section{Penanaman}

Penanaman bibit saat berumur 12 hari setelah semai atau ketika tanaman sudah mengeluarkan empat helai daun. Sebelum ditanam, media tanam yang ada di lahan penanaman sebaiknya disiram. Pemindahan bibit dilakukan sore hari setelah pukul 15.00.

\section{Pemberian pupuk NPK Mutiara}

Pemberian pupuk NPK Mutiara diberikan setelah tanam sesuai dengan dosis perlakuan yaitu $\left(\mathrm{n}_{0}\right)$ : tanpa pupuk NPK Mutiara atau kontrol, $\left(\mathrm{n}_{1}\right)$ : dengan dosis pupuk NPK Mutiara sebanyak 30 g/tanaman, $\left(\mathrm{n}_{2}\right)$ : dengan dosis pupuk NPK Mutiara sebanyak $60 \mathrm{~g} /$ tanaman dan $\left(\mathrm{n}_{3}\right)$ : dengan dosis pupuk NPK Mutiara sebanyak 90 g/tanaman. Pemberian puopuok NPK diberikan 3 kali yaitu umur 14, 28, 42 hari setelah tanam dengan cara pupuk NPK Mutiara diberikan $1 / 3$ tiap dosis perlakuan yaitu dengan cara ditabur secara merata dengan jarak $5 \mathrm{~cm}$ dari tanaman sesuai perlakuan kemudian di tutup kembali dengan tanah. Pemeliharaan Tanaman

Pemeliharaan tanaman meliputi:

a. Penyulaman

Penyulaman dilakukan 7 hari setelah tanam dengan cara mengganti 
tanaman yang pertumbuhannya kurang bagus atau mati.

b. Penyiangan

Penyiangan dilakukan setiap saat bila ada gulma yang tumbuh diantara barisan tanaman semangka dengan cara mencabut gulma tersebut.

c. Penyiraman

Penyiraman dilakukan satu hari sekali yaitu pagi atau sore hari atau penyiraman disesuaikan dengan kondisi di lapangan.

d. Pengendalian hama dan penyakit Untuk mencegah serangan nematoda ditaburkan insektisida furadan $3 \mathrm{G}$ pada awal tanam dengan $2 \mathrm{~g} /$ lubang tanam guna mengantisipasi serangan serangga. Untuk mengendalikan hama dan penyakit digunakan insektisida Agrimec 18 EC dengan dosis $0,5-1 \mathrm{ml} /$ liter bersamaan dengan penggunaan fungisida Antracol 70 WP dengan dosis 1,5 $\mathrm{mg} /$ liter. Pengendalian hama dan penyakit dilakukan 3 kali yaitu pada saat umur tanaman 14, 28, 42 hari setelah tanam. Penyemprotan pestisida dihentikan 2 minggu sebelum panen.

\section{Pemanenan}

Panen dilakukan apabila buah sudah masak yang ditandai sudah mengeringnya sulur dekat tangkai buah atau tangkai buah tampak kekuningan, buah tampak halus, bila buah diketuk dengan jari tangan akan bergetar dan terdengar seperti suara yang menggema. Cara panen yaitu memetik buah semangka beserta tangkainya menggunakan pisau dengan tujuan agar semangka dapat disimpan lebih lama.

\subsection{Pengambilan Data}

Adapun data yang akan diambil meliputi:

Panjang Tanaman $(\mathrm{cm})$

Pengukuran panjang tanaman sampel dilakukan dengan cara mengukur 5 $\mathrm{cm}$ diatas permukaan tanah dari pangkal batang sampai ujung tunas dengan menggunakan meteran. Pengukuran panjang tanaman dilakukan pada saat tanaman berumur 20, 40 dan 60 hari setelah tanam (cm).

Umur Keluar Bunga (hari)

Pengamatan keluar bunga dilakukan dengan menghitung jumlah hari, mulai dari saat tanam sampai tanaman mengeluarkan bunga pertama.

Umur Panen (hari)

Umur panen buah semangka yaitu mulai tanam sampai panen.

Diameter Buah (cm)

Pengukuran diameter buah dengan cara melilitkan tali pada bagian tengah buah kemudian mengukur tali tersebut dengan meteran, lalu di konversikan ke $d=k / \pi$.

Berat Buah Per Petak Produksi (kg) Berat buah di peroleh dengan cara menimbang berat buah per tanaman di dalam petak produksi.

Produksi Buah Per Hektar (ton/ha) Produksi buah per hektar di peroleh dengan cara menimbang berat buah per petak produksi, kemudian di konversikan ke dalam ton per hektar dengan rumus sebagai berikut: 


\subsection{Analisis Data}

Untuk mengetahui pengaruh pupuk Tanijau dan pupuk NPK Mutiara serta interaksinya terhadap pertumbuhan dan hasil tanaman semangka (Citrullus vulgaris Schard ) varietas Angela F1, dilakukan dengan menganalisis data hasil pengamatan dengan sidik ragam menurut (Steel dan Torrie,1991).

Bila hasil sidik ragam berpengaruh tidak nyata ( $\mathrm{F}$ hitung $\leq$
F tabel $5 \%$ ) tidak dilakukan uji lanjutan, sedangkan bila hasil sidik ragam berpengaruh nyata ( $\mathrm{F}$ hitung $>$ $\mathrm{F}$ tabel $5 \%$ ) atau berpengaruh sangat nyata ( $\mathrm{F}$ hitung $>\mathrm{F}$ tabel $1 \%$ ), maka untuk membandingkan dua rata-rata perlakuan dilakukan uji lanjutan dengan uji beda nyata terkecil (BNT) taraf $5 \%$. Rumus umum uji BNT sebagai berikut :

$$
\text { BNT } 5 \%=\mathrm{t} \text {-tabel } \mathrm{x} \sqrt{2 \mathrm{Ktgalat} / \mathrm{r}}
$$

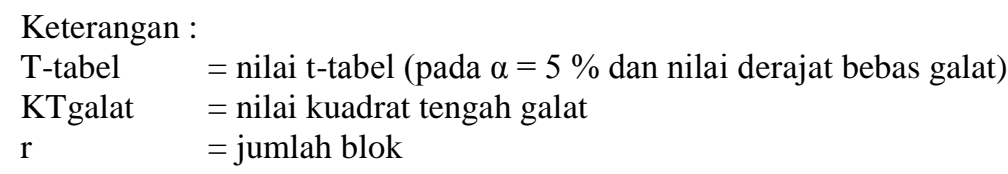

\section{HASIL PENELITIAN DAN PEMBAHASAN}

\subsection{Panjang Tanaman Umur 20 Hari Setelah Tanam $(\mathrm{cm})$}

Hasil sidik ragam menunjukan bahwa pemberian pupuk tanijau (A) dan pemberian pupuk NPK mutiara $(\mathrm{N})$ berpengaruh sangat nyata, sedangkan interaksi perlakuan $(\mathrm{AxN})$ berpengaruh tidak nyata terhadap panjang tanaman umur 20 hari setelah tanam.

Hasil uji BNT taraf $5 \%$ pada perlakuan pupuk tanijau (A) terhadap panjang tanaman umur 20 hari setelah tanam menunjukan bahwa perlakuan $\mathrm{a}_{3}, \mathrm{a}_{2}, \mathrm{a}_{1}$ dan $\mathrm{a}_{0}$ saling berbeda nyata satu sama lainya.

Hasil uji BNT taraf $5 \%$ pada perlakuan pupuk NPK Mutiara (N) terhadap panjang tanaman umur 20 hari setelah tanam menunjukan bahwa perlakuan $\mathrm{n}_{3}$ berbeda nyata dengan perlakuan $\mathrm{n}_{2}, \mathrm{n}_{1}$ dan $\mathrm{n}_{0}$. Perlakuan $\mathrm{n}_{2}$ tidak berbeda nyata dengan perlakuan $n_{1}$ tetapi berbeda nyata dengan perlakuan $\mathrm{n}_{0}$.
Perlakuan $\mathrm{n}_{1}$ tidak berbeda nyata dengan perlakuan $\mathrm{n}_{0}$.

\subsection{Panjang Tanaman Umur 40 Hari Setelah Tanam $(\mathrm{cm})$ \\ Hasil sidik ragam menunjukan} bahwa pemberian pupuk Tanijau (A) dan pemberian pupuk NPK Mutiara (N) berpengaruh sangat nyata, sedangkan interaksi perlakuan $(\mathrm{AxN})$ berpengaruh nyata terhadap panjang tanaman umur 40 hari setelah tanam.

Hasil uji BNT taraf $5 \%$ pada perlakuan pupuk tanijau (A) terhadap panjang tanaman umur 40 hari setelah tanam menunjukan bahwa perlakuan $\mathrm{a}_{3}, \mathrm{a}_{2}, \mathrm{a}_{1}$ dan $\mathrm{a}_{0}$ saling berbeda nyata satu sama lainya.

Hasil uji BNT taraf $5 \%$ pada perlakuan pupuk NPK Mutiara (N) terhadap panjang tanaman umur 40 hari setelah tanam menunjukan bahwa perlakuan $\mathrm{n}_{3}$ berbeda nyata dengan perlakuan $\mathrm{n}_{2}, \mathrm{n}_{1}$ dan $\mathrm{n}_{0}$. Perlakuan $\mathrm{n}_{2}$ berbeda nyata dengan perlakuan $\mathrm{n}_{1}$ dan $\mathrm{n}_{0}$. Perlakuan $\mathrm{n}_{1}$ tidak berbeda nyata dengan perlakuan $n_{0}$. 
Hasil uji BNT taraf $5 \%$ pada interaksi perlakuan pupuk tanijau dan pupuk NPK Mutiara (A x N) terhadap panjang tanaman umur 40 hari setelah tanam menunjukan bahwa perlakuan $\mathrm{a}_{3} \mathrm{n}_{3}$ tidak berbeda nyata dengan perlakuan $\mathrm{a}_{3} \mathrm{n}_{1}, \quad \mathrm{a}_{3} \mathrm{n}_{2}, \quad \mathrm{a}_{3} \mathrm{n}_{0}$, tetapi berbeda nyata dengan perlakuan $\mathrm{a}_{2} \mathrm{n}_{3}, \mathrm{a}_{1} \mathrm{n}_{3}, \mathrm{a}_{2} \mathrm{n}_{2}, \mathrm{a}_{2} \mathrm{n}_{1}$, $\mathrm{a}_{2} \mathrm{n}_{0}, \mathrm{a}_{1} \mathrm{n}_{2}, \mathrm{a}_{0} \mathrm{n}_{3}, \mathrm{a}_{1} \mathrm{n}_{1}, \mathrm{a}_{1} \mathrm{n}_{0}, \mathrm{a}_{0} \mathrm{n}_{2}, \mathrm{a}_{0} \mathrm{n}_{0}, \mathrm{a}_{0} \mathrm{n}_{1}$. Perlakuan $\mathrm{a}_{3} \mathrm{n}_{1}$ tidak berbeda nyata dengan perlakuan $\mathrm{a}_{3} \mathrm{n}_{2}, \mathrm{a}_{3} \mathrm{n}_{0}, \mathrm{a}_{2} \mathrm{n}_{3}$, tetapi berbeda nyata dengan perlakuan $\mathrm{a}_{1} \mathrm{n}_{3}$, $\mathrm{a}_{2} \mathrm{n}_{2}, \mathrm{a}_{2} \mathrm{n}_{1}, \mathrm{a}_{2} \mathrm{n}_{0}, \mathrm{a}_{1} \mathrm{n}_{2}, \mathrm{a}_{0} \mathrm{n}_{3}, \mathrm{a}_{1} \mathrm{n}_{1}, \mathrm{a}_{1} \mathrm{n}_{0}, \mathrm{a}_{0} \mathrm{n}_{2}$ $\mathrm{a}_{0} \mathrm{n}_{0}, \mathrm{a}_{0} \mathrm{n}_{1}$. Perlakuan $\mathrm{a}_{2} \mathrm{n}_{3}$ berbeda nyata dengan perlakuan $\mathrm{a}_{1} \mathrm{n}_{3}, \mathrm{a}_{2} \mathrm{n}_{2}, \mathrm{a}_{2} \mathrm{n}_{1}, \mathrm{a}_{2} \mathrm{n}_{0}$, $\mathrm{a}_{1} \mathrm{n}_{2}, \quad \mathrm{a}_{0} \mathrm{n}_{3}, \mathrm{a}_{1} \mathrm{n}_{1}, \mathrm{a}_{1} \mathrm{n}_{0}, \mathrm{a}_{0} \mathrm{n}_{2}, \mathrm{a}_{0} \mathrm{n}_{0}, \mathrm{a}_{0} \mathrm{n}_{1}$. Perlakuan $\mathrm{a}_{1} \mathrm{n}_{3}$ tidak berbeda nyata dengan perlakuan $a_{2} n_{2}, \quad a_{2} n_{1}$, tetapi berbeda nyata dengan perlakuan $\mathrm{a}_{2} \mathrm{n}_{0}$, $\mathrm{a}_{1} \mathrm{n}_{2}, \quad \mathrm{a}_{0} \mathrm{n}_{3}, \quad \mathrm{a}_{1} \mathrm{n}_{1}, \quad \mathrm{a}_{1} \mathrm{n}_{0}, \quad \mathrm{a}_{0} \mathrm{n}_{2}, \quad \mathrm{a}_{0} \mathrm{n}_{0}, \quad \mathrm{a}_{0} \mathrm{n}_{1}$ Perlakuan $\mathrm{a}_{2} \mathrm{n}_{2}$ tidak berbeda nyata dengan perlakuan $\mathrm{a}_{2} \mathrm{n}_{1}, \quad \mathrm{a}_{2} \mathrm{n}_{0}$ tetapi berbeda nyata dengan perlakuan $a_{1} n_{2}$, $\mathrm{a}_{0} \mathrm{n}_{3}, \mathrm{a}_{1} \mathrm{n}_{1}, \mathrm{a}_{1} \mathrm{n}_{0}, \mathrm{a}_{0} \mathrm{n}_{2}, \mathrm{a}_{0} \mathrm{n}_{0}, \mathrm{a}_{0} \mathrm{n}_{1}$. Perlakuan $\mathrm{a}_{2} \mathrm{n}_{1}$ tidak berbeda nyata dengan perlakuan $\mathrm{a}_{2} \mathrm{n}_{0}, \mathrm{a}_{1} \mathrm{n}_{2}$, tetapi berbeda nyata dengan perlakuan $\mathrm{a}_{0} \mathrm{n}_{3}, \mathrm{a}_{1} \mathrm{n}_{1}, \mathrm{a}_{1} \mathrm{n}_{0}, \mathrm{a}_{0} \mathrm{n}_{2}$, $\mathrm{a}_{0} \mathrm{n}_{0}, \mathrm{a}_{0} \mathrm{n}_{1}$. Perlakuan $\mathrm{a}_{2} \mathrm{n}_{0}$ tidak berbeda nyata dengan perlakuan $\mathrm{a}_{1} \mathrm{n}_{2}, \mathrm{a}_{0} \mathrm{n}_{3}, \mathrm{a}_{1} \mathrm{n}_{1}$ tetapi berbeda nyata dengan perlakuan $\mathrm{a}_{1} \mathrm{n}_{0}, \mathrm{a}_{0} \mathrm{n}_{2}, \mathrm{a}_{0} \mathrm{n}_{0}, \mathrm{a}_{0} \mathrm{n}_{1}$. Perlakuan $\mathrm{a}_{1} \mathrm{n}_{1}$ tidak berbeda nyata dengan perlakuan $\mathrm{a}_{1} \mathrm{n}_{0}$, $\mathrm{a}_{0} \mathrm{n}_{2}$ tetapi berbeda nyata dengan perlakuan $a_{0} n_{0}, \quad a_{0} n_{1}$. Perlakuan $a_{0} n_{2}$, $\mathrm{a}_{0} \mathrm{n}_{0}, \mathrm{a}_{0} \mathrm{n}_{1}$ satu sama lainya saling tidak berbeda nyata.

\subsection{Panjang Tanaman Umur 60 Hari Setelah Tanam $(\mathrm{cm})$}

Hasil sidik ragam menunjukan bahwa pemberian pupuk Tanijau (A) dan pemberian pupuk NPK Mutiara (N) berpengaruh sangat nyata, sedangkan interaksi perlakuan $(\mathrm{AxN})$ berpengaruh nyata terhadap panjang tanaman umur 60 hari setelah tanam.
Hasil uji BNT taraf $5 \%$ pada perlakuan pupuk tanijau (A) terhadap panjang tanaman umur 60 hari setelah tanam menunjukan bahwa perlakuan $\mathrm{a}_{3}, \mathrm{a}_{2}, \mathrm{a}_{1}$ dan $\mathrm{a}_{0}$ saling berbeda nyata satu sama lainya.

Hasil uji BNT taraf $5 \%$ pada perlakuan pupuk NPK Mutiara (N) terhadap panjang tanaman umur 60 hari setelah tanam menunjukan bahwa perlakuan $\mathrm{n}_{3}$ berbeda nyata dengan perlakuan $\mathrm{n}_{2}, \mathrm{n}_{1}$ dan $\mathrm{n}_{0}$. Perlakuan $\mathrm{n}_{2}$ berbeda nyata dengan perlakuan $\mathrm{n}_{1}$ dan $\mathrm{n}_{0}$. Perlakuan $\mathrm{n}_{1}$ tidak berbeda nyata dengan perlakuan $n_{0}$.

Hasil uji BNT taraf $5 \%$ pada interaksi perlakuan pupuk tanijau dan pupuk NPK Mutiara (A x N) terhadap panjang tanaman umur 60 hari setelah tanam menunjukan bahwa perlakuan $\mathrm{a}_{3} \mathrm{n}_{3}$ tidak berbeda nyata dengan perlakuan $\mathrm{a}_{3} \mathrm{n}_{2}, \quad \mathrm{a}_{3} \mathrm{n}_{0}, \quad \mathrm{a}_{3} \mathrm{n}_{1}$, tetapi berbeda nyata dengan perlakuan $a_{2} n_{3}, \quad a_{1} n_{3}, \quad a_{2} n_{2}$, $\mathrm{a}_{2} \mathrm{n}_{1}, \mathrm{a}_{1} \mathrm{n}_{2}, \mathrm{a}_{2} \mathrm{n}_{0}, \mathrm{a}_{0} \mathrm{n}_{3}, \mathrm{a}_{1} \mathrm{n}_{1}, \mathrm{a}_{1} \mathrm{n}_{0}, \mathrm{a}_{0} \mathrm{n}_{2}, \mathrm{a}_{0} \mathrm{n}_{0}$, $\mathrm{a}_{0} \mathrm{n}_{1}$. Perlakuan $\mathrm{a}_{3} \mathrm{n}_{2}$ tidak berbeda nyata dengan perlakuan $\mathrm{a}_{3} \mathrm{n}_{0}, \mathrm{a}_{3} \mathrm{n}_{1}, \mathrm{a}_{2} \mathrm{n}_{3}$ tetapi berbeda nyata dengan perlakuan $\mathrm{a}_{1} \mathrm{n}_{3}$, $\mathrm{a}_{2} \mathrm{n}_{2}, \mathrm{a}_{2} \mathrm{n}_{1}, \mathrm{a}_{1} \mathrm{n}_{2}, \mathrm{a}_{2} \mathrm{n}_{0}, \mathrm{a}_{0} \mathrm{n}_{3}, \mathrm{a}_{1} \mathrm{n}_{1}, \mathrm{a}_{1} \mathrm{n}_{0}, \mathrm{a}_{0} \mathrm{n}_{2}$ $\mathrm{a}_{0} \mathrm{n}_{0}, \mathrm{a}_{0} \mathrm{n}_{1}$. Perlakuan $\mathrm{a}_{2} \mathrm{n}_{3}$ berbeda nyata dengan perlakuan $\mathrm{a}_{1} \mathrm{n}_{3}, \mathrm{a}_{2} \mathrm{n}_{2}, \mathrm{a}_{2} \mathrm{n}_{1}, \mathrm{a}_{1} \mathrm{n}_{2}$, $\mathrm{a}_{2} \mathrm{n}_{0}, \mathrm{a}_{0} \mathrm{n}_{3}, \mathrm{a}_{1} \mathrm{n}_{1}, \mathrm{a}_{1} \mathrm{n}_{0}, \mathrm{a}_{0} \mathrm{n}_{2}, \mathrm{a}_{0} \mathrm{n}_{0}, \mathrm{a}_{0} \mathrm{n}_{1}$. Perlakuan $\mathrm{a}_{1} \mathrm{n}_{3}$ tidak berbeda nyata dengan perlakuan $\mathrm{a}_{2} \mathrm{n}_{2}$ tetapi berbeda nyata dengan perlakuan $\mathrm{a}_{2} \mathrm{n}_{1}, \mathrm{a}_{1} \mathrm{n}_{2}, \mathrm{a}_{2} \mathrm{n}_{0}$, $a_{0} n_{3}, \quad a_{1} n_{1}, \quad a_{1} n_{0}, \quad a_{0} n_{2}, \quad a_{0} n_{0}, \quad a_{0} n_{1}$ Perlakuan $\mathrm{a}_{2} \mathrm{n}_{2}$ tidak berbeda nyata dengan perlakuan $a_{2} n_{1}, a_{1} n_{2}, a_{2} n_{0}$ tetapi berbeda nyata dengan perlakuan $a_{0} n_{3}$, $\mathrm{a}_{1} \mathrm{n}_{1}, \mathrm{a}_{1} \mathrm{n}_{0}, \mathrm{a}_{0} \mathrm{n}_{2}, \mathrm{a}_{0} \mathrm{n}_{0}, \mathrm{a}_{0} \mathrm{n}_{1}$. Perlakuan $\mathrm{a}_{2} \mathrm{n}_{1}$ tidak berbeda nyata dengan perlakuan $\mathrm{a}_{1} \mathrm{n}_{2}, \mathrm{a}_{2} \mathrm{n}_{0}, \mathrm{a}_{0} \mathrm{n}_{3}, \mathrm{a}_{1} \mathrm{n}_{1}$ tetapi berbeda nyata dengan perlakuan $\mathrm{a}_{1} \mathrm{n}_{0}, \mathrm{a}_{0} \mathrm{n}_{2}, \mathrm{a}_{0} \mathrm{n}_{0}, \mathrm{a}_{0} \mathrm{n}_{1}$. Perlakuan $\mathrm{a}_{1} \mathrm{n}_{2}$ tidak berbeda nyata dengan perlakuan $\mathrm{a}_{2} \mathrm{n}_{0}, \mathrm{a}_{0} \mathrm{n}_{3}, \mathrm{a}_{1} \mathrm{n}_{1}, \mathrm{a}_{1} \mathrm{n}_{0}$ tetapi berbeda nyata dengan perlakuan $\mathrm{a}_{0} \mathrm{n}_{2}, \quad \mathrm{a}_{0} \mathrm{n}_{0}, \quad \mathrm{a}_{0} \mathrm{n}_{1}$. Perlakuan $\mathrm{a}_{2} \mathrm{n}_{0}$ tidak berbeda nyata dengan perlakuan $\mathrm{a}_{0} \mathrm{n}_{3}$, $\mathrm{a}_{1} \mathrm{n}_{1}, \quad \mathrm{a}_{1} \mathrm{n}_{0}, \quad \mathrm{a}_{0} \mathrm{n}_{2}$ tetapi berbeda nyata 
dengan perlakuan $\mathrm{a}_{0} \mathrm{n}_{0}, \mathrm{a}_{0} \mathrm{n}_{1}$. Perlakuan $\mathrm{a}_{0} \mathrm{n}_{2}$ tidak berbeda nyata dengan perlakuan $\mathrm{a}_{0} \mathrm{n}_{0}$ tetapi berbeda nyata dengan perlakuan $a_{0} n_{1}$. Perlakuan $a_{0} n_{0}$ dan $\mathrm{a}_{0} \mathrm{n}_{1}$ saling tidak berbeda nyata.

\subsection{Umur Keluar Bunga}

Hasil sidik ragam menunjukan bahwa pemberian pupuk Tanijau (A) berpengaruh sangat nyata, pemberian pupuk NPK Mutiara (N) berpengaruh nyata, sedangkan interaksi perlakuan $(\mathrm{AxN})$ berpengaruh tidak nyata terhadap umur keluar bunga.

Hasil uji BNT taraf $5 \%$ pada perlakuan pupuk tanijau (A) terhadap umur keluar bunga pertama menunjukan bahwa perlakuan $\mathrm{a}_{0}, \mathrm{a}_{1}, \mathrm{a}_{2}$ dan $\mathrm{a}_{3}$ saling berbeda nyata satu sama lainya.

Hasil uji BNT taraf $5 \%$ pada perlakuan pupuk NPK Mutiara (N) terhadap umur keluar bunga pertama menunjukan bahwa perlakuan $\mathrm{n}_{3}$ tidak berbeda nyata dengan perlakuan $\mathrm{n}_{2}$ dan $\mathrm{n}_{1}$, tetapi berbeda nyata dengan perlakuan $\mathrm{n}_{0}$. Perlakuan $\mathrm{n}_{1}$ berbeda nyata dengan perlakuan $\mathrm{n}_{0}$.

\subsection{Umur Panen}

Hasil sidik ragam menunjukan bahwa pemberian pupuk Tanijau (A), pemberian pupuk NPK Mutiara (N) serta interaksi perlakuan $(\mathrm{AxN})$ berpengaruh tidak nyata terhadap umur panen.

\subsection{Diameter Buah}

Hasil sidik ragam menunjukan bahwa pemberian pupuk Tanijau (A) dan pemberian pupuk NPK Mutiara (N) berpengaruh sangat nyata, sedangkan interaksi perlakuan $(\mathrm{AxN})$ berpengaruh tidak nyata terhadap umur panen.

Hasil uji BNT taraf $5 \%$ pada perlakuan pupuk tanijau (A) terhadap diameter buah menunjukan bahwa perlakuan $a_{3}, a_{2}, a_{1}$ dan $a_{0}$ saling berbeda nyata satu sama lainya.
Hasil uji BNT taraf $5 \%$ pada perlakuan pupuk NPK Mutiara (N) terhadap diameter buah menunjukan bahwa perlakuan $\mathrm{n}_{3}, \mathrm{n}_{2}, \mathrm{n}_{1}$ dan $\mathrm{n}_{0}$ saling berbeda nyata satu sama lainya.

\subsection{Berat Buah Per Petak Produksi}

Hasil sidik ragam menunjukan bahwa pemberian pupuk Tanijau (A) dan pemberian pupuk NPK Mutiara (N) berpengaruh sangat nyata, sedangkan interaksi perlakuan $(\mathrm{AxN})$ berpengaruh tidak nyata terhadap berat buah per petak produksi.

Hasil uji BNT taraf $5 \%$ pada perlakuan pupuk tanijau (A) terhadap berat buah per petak produksi menunjukan bahwa perlakuan $\mathrm{a}_{3}, \mathrm{a}_{2}, \mathrm{a}_{1}$ dan $a_{0}$ saling berbeda nyata satu sama lainya.

Hasil uji BNT taraf $5 \%$ pada perlakuan pupuk NPK Mutiara (N) terhadap berat buah per petak produksi menunjukan bahwa perlakuan $\mathrm{n}_{3}$ berbeda nyata dengan perlakuan $\mathrm{n}_{2}, \mathrm{n}_{1}$ dan $\mathrm{n}_{0}$. Perlakuan $\mathrm{n}_{2}$ berbeda nyata dengan perlakuan $\mathrm{n}_{0}$ dan $\mathrm{n}_{1}$. Perlakuan $\mathrm{n}_{0}$ tidak berbeda nyata dengan perlakuan $n_{1}$.

\subsection{Produksi Buah Per Hektar}

Hasil sidik ragam menunjukan bahwa pemberian pupuk Tanijau (A) dan pemberian pupuk NPK Mutiara $(\mathrm{N})$ berpengaruh sangat nyata, sedangkan interaksi perlakuan $(\mathrm{AxN})$ berpengaruh tidak nyata terhadap produksi buah per hektar.

Hasil uji BNT taraf $5 \%$ pada perlakuan pupuk tanijau (A) terhadap produksi buah per hektar menunjukan bahwa perlakuan $\mathrm{a}_{3}, \mathrm{a}_{2}, \mathrm{a}_{1}$ dan $\mathrm{a}_{0}$ saling berbeda nyata satu sama lainya.

Hasil uji BNT taraf $5 \%$ pada perlakuan pupuk NPK Mutiara (N) terhadap produksi buah per hektar menunjukan bahwa perlakuan $\mathrm{n}_{3}$ berbeda nyata dengan perlakuan $\mathrm{n}_{2}, \mathrm{n}_{1}$ dan $\mathrm{n}_{0}$. Perlakuan $\mathrm{n}_{2}$ berbeda nyata dengan 
perlakuan $\mathrm{n}_{0}$ dan $\mathrm{n}_{1}$. Perlakuan $\mathrm{n}_{0}$ tidak berbeda nyata dengan perlakuan $\mathrm{n}_{1}$.

Tabel 1. Rekapitulasi Data Penelitian Pengaruh Pupuk Tanijau dan NPK Mutiara Terhadap Pertumbuhan dan Hasil Tanaman Semangka (Citrullus vulgaris Schard) Varietas Angela F1.

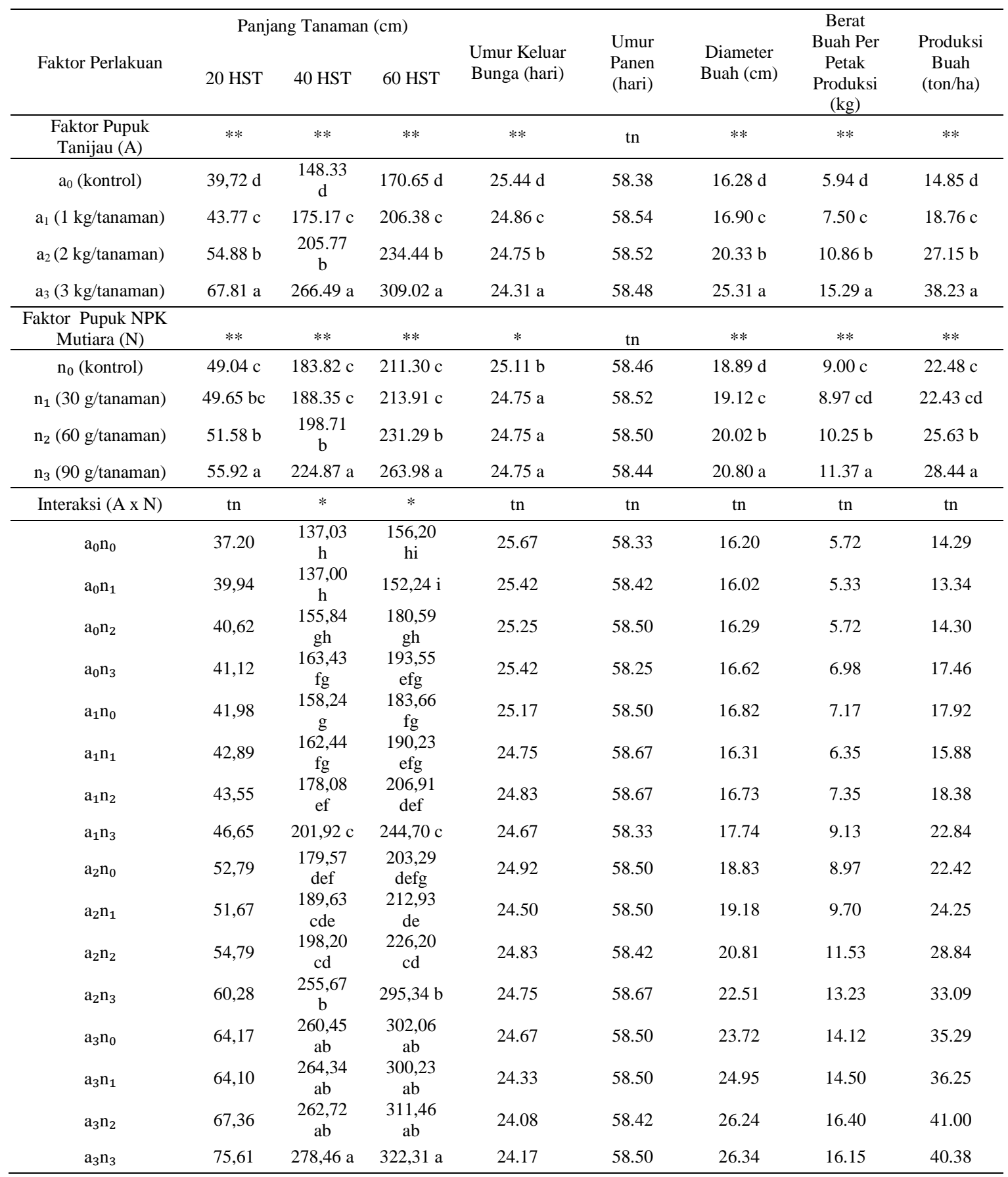

Keterangan :

$* *=$ Berbeda Sangat Nyata, $*=$ Berbeda Nyata, $\mathrm{tn}=$ Berbeda Tidak Nyata, HST $=$ Hari Setelah Tanam Angka yang di ikuti oleh huruf yang sama menunjukkan berbeda tidak nyata pada Uji BNT $5 \%$

Pengaruh Pupuk Tanijau Terhadap Tanaman Semangka (Citrullus vulgaris Schard) Varietas Angela F1. Hasil sidik ragam menunjukan bahwa perlakuan pupuk Tanijau berpengaruh sangat nyata terhadap panjang tanaman umur 20, 40 
dan 60 hari setelah tanam. Tanaman terpanjang terdapat pada perlakuan $\mathrm{a}_{3}$ (dosis pupuk Tanijau 30 ton/ha), yaitu $67,81 \mathrm{~cm}$ pada umur 20 hari setelah tanam, 266,49 pada umur 40 hari setelah tanam dan 309,02 cm pada umur 60 hari setelah tanam, sedangkan tanaman terpendek terdapat pada perlakuan $\mathrm{a}_{0}$ (perlakuan tanpa pupuk Tanijau atau kontrol) yaitu $39,72 \mathrm{~cm}$ pada umur 20 hari setelah tanam, 148,33 $\mathrm{cm}$ pada umur 40 hari setelah tanam dan $170,65 \mathrm{~cm}$ pada umur 60 hari setelah tanam. Semakin meningkatkan pupuk Tanijau yang diberikan, maka semakin meningkatkan pula panjang tanaman. Keadaan ini disebabkan adanya peranan unsur $\mathrm{N}$ (nitrogen) yang terdapat dalam pupuk Tanijau (kadarnya N 3,36 \%). Dengan bertambahnya umur tanaman semangka, maka kebutuhan terhadap unsur hara bertambah banyak. Perlakuan pemberian pupuk Tanijau menghasil tanaman yang lebih panjang dibandingkan dengan perlakuan tanpa pupuk Tanijau. Hal ini disebabkan dengan pemberian pupuk Tanijau akan meningkatkan ketersedian unsur hara dalam tubuh tanaman, terutama unsur hara $\mathrm{N}$ (nitrogen) yang sangat dibutuhkan untuk pertumbuhan vegetatif tanaman karena dengan pemberian unsur nitrogen, tanaman akan banyak mengandung zat hijau daun atau klorofil yang penting dalam proses fotosintesis dan mempercepat pertumbuhan dan bertambahnya panjang tanaman (Parnata, 2010). Seperti dikemukakan oleh (Sutedjo dan Kartasapoetra, 1990) yang menyatakan bahwa ketersedian unsur $\mathrm{N}$ (nitrogen) di dalam tubuh tanaman dapat menghasilkan protein yang lebih banyak, semakin banyak unsur nitrogen yang diberikan, maka semakin cepat pula sintesis karbohidrat yang diubah menjadi protein dan protoplasma. Peningkatan jumlah unsur hara nitrogen dalam tubuh tanaman akan meningkat kadar protein dalam jaringan tanaman yang digunakan dalam pertumbuhan vegetatif tanaman.

Hasil analisis tanah berdasarkan kriteria kesuburan tanah, terlihat bahwa $\mathrm{pH}$ tanah 3,8 (sangat rendah) dan unsur $\mathrm{P}$ 5,1 (sangat rendah). Hal ini menggambarkan bahwa $\mathrm{pH}$ tanah yang rendah dan masih rendahnya ketersediaan unsur hara makro di dalam tanah, sehingga perlu dilakukan pengapuran dan pemupukan dengan pupuk Tanijau. Fungsi dari pengapuran untuk menaikkan $\mathrm{pH}$ tanah dari asam ke posisi netral dan pupuk Tanijau yang dapat mempercepat umur keluar bunga pertama. Berdasarkan data pada Tabel 1 (Tabel Rekapitulasi) perlakuan pupuk Tanijau dengan dosis 30 ton/ha $\left(\mathrm{a}_{3}\right)$ mempercepat keluarnya bunga yaitu umur 24,31 hari dibandingkan dengan perlakuan tanpa pupuk Tanijau $\left(\mathrm{a}_{0}\right)$, yaitu umur 25,44 hari. Hal ini disebabkan adanya peranan unsur $P$ (fosfor) yang terdapat dalam pupuk Tanijau ( kadarnya $\mathrm{P}_{2} \mathrm{O}_{5}$ 2,54\%) yang akan meningkatkan ketersedian unsur hara dalam tubuh tanaman, unsur ini sangat dibutuhkan untuk pertumbuhan generatif tanaman sebagaimana dikemukakan oleh (Marsono dan Sigit, 2005) dengan pemberian unsur fosfor, akan merangsang pertumbuhan dan perkembangan akar, sebagai bahan dasar protein, membantu asimilasi dan respirasi mempercepat proses pembungaan pada tanaman.

Hasil sidik ragam menunjukan bahwa perlakuan pupuk Tanijau berpengaruh sangat nyata terhadap diameter buah, berat buah per petak produksi dan produksi buah. Secara umum diameter buah terbesar, berat buah per petak produksi tertinggi dan produksi buah tertinggi terdapat pada perlakuan $\mathrm{a}_{3}$ (dosis pupuk Tanijau 30 ton/ha), yaitu $25,31 \mathrm{~cm}, 15,29 \mathrm{~kg}$ dan 38,23 ton/ha. Berat buah pertanaman ini masih rendah dibandingkan dengan deskripsinya 5,0 $6,2 \mathrm{~kg} /$ buah sedangkan hasil penelitian 
paling tinggi $3,82 \mathrm{~kg} /$ buah dan yang terendah $1,49 \mathrm{~kg} / \mathrm{buah}$, sedangkan diameter buah terkecil, berat buah per petak produksi terendah dan produksi buah terendah terdapat pada perlakuan $\mathrm{a}_{0}$ (perlakuan tanpa pupuk Tanijau atau kontrol) yaitu $16,28 \mathrm{~cm}, 5,94 \mathrm{~kg}$ dan 14,85 ton/ha. Hal ini disebabkan adanya peranan unsur fosfor dan kalium yang terdapat dalam pupuk Tanijau (kadarnya $\mathrm{P}_{2} \mathrm{O}_{5} \quad 2,54 \%$ dan $\mathrm{K}_{2} \mathrm{O} \quad 2,64 \%$ ) akan meningkatkan ketersediaan unsur hara di dalam tanah, sehingga memungkinkan akar tanaman untuk menyerap unsurunsur tersebut, yang diperlukan bagi pertumbuhan generatif tanaman semangka terutama pada diameter buah, berat buah dan produksi buah.

Pengaruh Pupuk NPK Mutiara Terhadap Tanaman Semangka (Citrullus vulgaris Schard) Varietas Angela F1. Hasil sidik ragam menunjukan bahwa perlakuan pupuk NPK Mutiara berpengaruh sangat nyata terhadap panjang tanaman umur 20, 40 dan 60 hari setelah tanam. Tanaman terpanjang terdapat pada perlakuan $\mathrm{n}_{3}$ (dosis pupuk Tanijau $900 \mathrm{~kg} / \mathrm{ha}$ ), yaitu $55,92 \mathrm{~cm}$ pada umur 20 hari setelah tanam, 224,87 $\mathrm{cm}$ pada umur 40 hari setelah tanam dan $263,98 \mathrm{~cm}$ pada umur 60 hari setelah tanam, sedangkan tanaman terpendek terdapat pada perlakuan $\mathrm{n}_{0}$ (perlakuan tanpa pupuk NPK Mutiara atau kontrol) yaitu 49,04 $\mathrm{cm}$ pada umur 20 hari setelah tanam, $183,82 \mathrm{~cm}$ pada umur 40 hari setelah tanam dan $211,30 \mathrm{~cm}$ pada umur 60 hari setelah tanam. Hal ini disebabkan adanya unsur $\mathrm{N}$ (nitrogen) sebesar $16 \%$ yang mampu meningkat ketersediaan unsur hara di dalam tanah, sehingga memungkinkan akar tanaman untuk menyerap unsur tersebut, yang diperlukan bagi pertumbuhan vegetatif tanaman semangka terutama pada batang tanaman, jumlah daun dan perkembangan akar. Sebagaimana dikemukakan oleh (Sutedjo,
2008) bahwa unsur nitrogen dibutuhkan untuk pembentukan atau pertumbuhan bagian vegetatif, seperti pembentukan batang, daun dan akar.

Hasil sidik ragam menunjukan bahwa perlakuan pupuk NPK Mutiara berpengaruh nyata terhadap umur keluar bunga pertama. Berdasarkan data pada Tabel 1 (Tabel Rekapitulasi) perlakuan pupuk NPK Mutiara dengan dosis 900 $\mathrm{kg} / \mathrm{ha}\left(\mathrm{n}_{3}\right)$ mempercepat keluarnya bunga yaitu umur 24,75 hari dibandingkan dengan perlakuan tanpa pupuk Tanijau $\left(\mathrm{n}_{0}\right)$, yaitu umur 25,11 hari. Keadaan ini diduga dengan adanya unsur $\mathrm{P}$ (fosfor) akan meningkatkan ketersedian unsur hara dalam tubuh tanaman, unsur ini sangat dibutuhkan untuk pertumbuhan generatif tanaman karena dengan pemberian unsur fosfor, akan memperbesar persentase terbentuknya bunga.

Hasil sidik ragam menunjukan bahwa perlakuan pupuk NPK Mutiara berpengaruh sangat nyata terhadap diameter buah. Berdasarkan data pada (Tabel 1) perlakuan pupuk NPK Mutiara dengan dosis $900 \mathrm{~kg} / \mathrm{ha}\left(\mathrm{n}_{3}\right)$ memperoleh diameter buah terbesar yaitu $20,80 \mathrm{~cm}$ dibandingkan dengan perlakuan tanpa pupuk NPK Mutiara $\left(\mathrm{n}_{0}\right)$, yaitu $18,89 \mathrm{~cm}$. Hal ini disebabkan karena pupuk NPK Mutiara mengandung unsur hara $P$ (fosfor) berfungsi untuk menyimpan dan transfer energi ke seluruh aktivitas metabolisme tanaman sehingga dengan adanya unsur $\mathrm{P}$ akan memperbesar persentase terbentuknya bunga menjadi buah.

Hasil sidik ragam menunjukan bahwa perlakuan pupuk NPK Mutiara berpengaruh sangat nyata terhadap, berat buah per petak produksi dan produksi buah. Secara umum berat buah perpetak produksi dan produksi buah per hektar ter tinggi terdapat pada perlakuan $\mathrm{n}_{3}$ (dosis pupuk NPK Mutiara $900 \mathrm{~kg} / \mathrm{ha}$, yaitu $11,37 \mathrm{~kg}$ dan 28,44 ton/ha) sedangkan 
berat buah perpetak produksi dan produksi buah per hektar ter terendah terdapat pada perlakuan $\mathrm{n}_{1}$ (dosis 300 $\mathrm{kg} / \mathrm{ha}$, yaitu $8,97 \mathrm{~kg}$ dan 22,43 ton/ha). Sedangkan produksi berat buah pertanaman berdasarkan penelitian yang paling tinggi $2,84 \mathrm{~kg} /$ buah dan yang terendah $2,25 \mathrm{~kg} / \mathrm{buah}$. Berat buah ini masih rendah dibandingkan deskripsinya yaitu 5,0 - 6,2 kg/ buah. Rendahnya produksi berat buah pertanaman ini disebabkan karena curah hujan lebih tinggi pada saat penelitian yaitu rata-rata $161 \mathrm{~mm} /$ bulan. Sedangkan syarat tumbuh tanaman semangka memerlukan curah hujan $40-50 \mathrm{~mm} /$ bulan. Dengan adanya curah hujan yang tinggi pada saat penelitian menyebabkan akar tanaman terendam air sehingga mengganggu penyerapan unsur hara.

Pengaruh Interaksi Perlakuan Pupuk Tanijau dan NPK Mutiara Terhadap Tanaman Semangka (Citrullus vulgaris Schard) Varietas Angela F1.

Hasil sidik ragam menunjukan bahwa interaksi perlakuan antara pupuk Tanijau dan pupuk NPK Mutiara berpengaruh nyata terhadap parameter terhadap panjang tanaman 40 dan 60 hari setelah tanam. Tidak berpengaruh nyata terhadap panjang tanaman umur 20 hari setelah tanam, umur keluar bunga pertama, umur panen, diameter buah, berat buah per petak produksi dan produksi buah.

Secara umum interaksi perlakuan pupuk Tanijau dan pupuk NPK Mutiara memberikan hasil yang signifikan pada parameter panjang tanaman umur 40 dan 60 hari setelah tanam. Hal ini dapat dilihat pada Tabel 1, ada kecenderungan terjadi peningkatan pertumbuhan pada fase vegetatif seperti panjang tanaman. Tanaman terpanjang terdapat pada perlakuan $\mathrm{a}_{3} \mathrm{n}_{3}$ yaitu $278,46 \mathrm{~cm}$ pada umur 40 hari setelah tanam dan 322,31 $\mathrm{cm}$ pada umur 60 hari setelah tanam, sedangkan tanaman terpendek terdapat pada perlakuan $\mathrm{a}_{0} \mathrm{n}_{1}$ yaitu $137,00 \mathrm{~cm}$ pada umur 40 hari setelah tanam dan 152,24 $\mathrm{cm}$ pada umur 60 hari setelah tanam.

Meskipun hasil sidik ragam berpengaruh tidak nyata, namun hasil rekapitulasi penelitian memperlihatkan adanya kecenderungan bahwa pada parameter berat buah per petak produksi dan produksi buah cenderung meningkat. Secara umum berat buah perpetak produksi dan produksi buah per hektar ter tinggi terdapat pada perlakuan $\mathrm{a}_{3} \mathrm{n}_{2}$ (dosis pupuk Tanijau 30 ton/ha dan dosis pupuk NPK Mutiara $600 \mathrm{~kg} / \mathrm{ha}$, yaitu 16,40 kg dan 41,00 ton/ha). Berat buah pertanaman ini masih rendah dibandingkan dengan deskripsinya $5,0-6,2 \mathrm{~kg} /$ buah sedangkan hasil penelitian paling tinggi $4,04 \mathrm{~kg} /$ buah dan yang terendah 1,43 $\mathrm{kg} /$ buah. Sedangkan berat buah perpetak produksi dan produksi buah per hektar ter terendah terdapat pada perlakuan $\mathrm{a}_{0} \mathrm{n}_{1}$ (perlakuan tanpa pupuk Tanijau atau kontrol dan dosis $300 \mathrm{~kg} / \mathrm{ha}$, yaitu 5,33 $\mathrm{kg}$ dan 13,34 ton/ha). Hal ini menunjukan bahwa pemberian pupuk Tanijau dan pemberian pupuk NPK Mutiara menghasilkan pertumbuhan dan hasil yang baik.

\section{KESIMPULAN}

Kesimpulan dari hasil penelitian adalah : Perlakuan pupuk Tanijau tidak berpengaruh nyata terhadap parameter umur panen. Perlakuan pupuk Tanijau berpengaruh sangat nyata terhadap parameter panjang tanaman umur 20, 40 dan 60, umur keluar bunga pertama, diameter buah, berat buah per petak produksi dan produksi buah. Produksi buah per hektar ter tinggi terdapat pada perlakuan $a_{3}$ (dosis pupuk Tanijau 30 ton/ha), yaitu 38,23 ton/ha, sedangkan produksi buah terendah terdapat pada perlakuan $\mathrm{a}_{0}$ (dosis tanpa pupuk Tanijau atau kontrol), yaitu 14,85 ton/ha. 
Perlakuan pupuk NPK Mutiara tidak berpengaruh nyata terhadap parameter umur panen dan berpengaruh nyata terhadap parameter saat keluar bunga pertama. Berpengaruh sangat nyata terhadap parameter panjang tanaman umur 20, 40 dan 60, diameter buah, berat buah per petak produksi dan produksi buah. Produksi buah tertinggi terdapat pada perlakuan $\mathrm{n}_{3}$ (dosis pupuk NPK Mutiara $900 \mathrm{~kg} / \mathrm{ha}$ ), yaitu 28.44 ton/ha, sedangkan produksi buah terendah terdapat pada perlakuan $\mathrm{n}_{1}$ (dosis pupuk $300 \mathrm{~kg} / \mathrm{ha}$ ), yaitu 22,43 ton/ha.

Interaksi perlakuan antara pupuk Tanijau dan NPK Mutiara berpengaruh nyata terhadap parameter terhadap panjang tanaman umur 20, 40 dan 60 hari setelah tanam tetapi tidak berpengaruh nyata terhadap umur keluar bunga pertama, umur panen, diameter buah, berat buah per petak produksi dan produksi buah.

\section{DAFTAR PUSTAKA}

Barus, A dan Syukri. (2008). Agroteknologi Tanaman BuahBuahan. Medan: Usu Press.

Frajnanta, F. (2001). Kiat Sukses Bertanam Semangka Berbiji. Jakarta: Penebar Swadaya.

Hadisuwito, S. (2012). Membuat Pupuk Organik Cair. Jakarta: Agromedia Pustaka.
Novizan. (2007). Petunjuk Pemupukan Yang Efektif. Jakarta: Agro Media Pustaka.

Parnata, A. (2010). Meningkatkan Hasil Panen dengan Pupuk Organik. Jakarta: Agromedia Pustaka.

Sutedjo, M. (2008). Pupuk dan Cara Pemupukan. Jakarta: Rineka Cipta.

Sigit dan Marsono. (2001). Pupuk Akar Jenis dn Aplikasi. Jakarta: Penebar Swadaya.

Soedarya, A.P. (2009). Budidaya Usaha Pengolahan Agribisnis Semangka. Bandung: Pustaka Gravita.

Steel, Robert G. D dan Torrie, James. H. (1991). Prinsip dan Prosedur Statistika. Suatu Pendekatan Biometrik. (Terjemahan Bambang Sumantri). Jakarta: Gramedia Pustaka Utama.

Sutejo M. M. dan Kartasapoetra A. G. (1990). Pupuk dan Cara Pemupukan. Jakarta: Rineka Cipta.

Unitekborneo. (2015). Pupuk Tanijau. Diakses 01 Februari 2018, dari http://www.unitekborneo.com/201 5/04/pupukorganiktanijau28.html. 